\title{
Detection and Quantification of Major Phytochemical Markers for Standardization of Talinum portulacifolium, Gomphrena serrata, Alternanthera sessilis and Euphorbia heterophylla by HPLC
}

\author{
Mamillapalli Vani ${ }^{1 *}$, Shaik Abdul Rahaman ${ }^{2}$, Avula Prameela Rani ${ }^{3}$
}

\section{Mamillapalli Vani ${ }^{*}$, Shaik Abdul Rahaman², Avula Prameela Rani ${ }^{3}$}

\section{'Department of Pharmacy, Jawaha- rlal Nehru Technological University, Kakinada, East Godavari (Dt.), Andhra Pradesh, INDIA, 'Department of Phar- macognosy and Phytochemistry, Vijaya Institute of Pharmaceutical Sciences for Women, Enikepadu, Vijayawada, Krishna, Andhra Pradesh, INDIA. ${ }^{2}$ Department of Medicinal Chemistry, Principal, Nirmala College of Pharmacy, Atmakur, Mangalagiri, Guntur, Andhra Pradesh, INDIA. \\ ${ }^{3}$ Department of Pharmaceutics, Univer- sity College of Pharmaceutical Sciences, Acharya Nagarjuna University, Nagar- junanagar, Guntur, INDIA. \\ Correspondence \\ Mamillapalli Vani}

Department of Pharmacognosy and Phyto Chemistry, Vijaya Institute of Pharmaceutical Sciences for Women, Enikepadu, Vijayawada, INDIA.

Phone: 9704625782

E-mail: vanimamillapalli@yahoo.co.in

\section{History}

- Submission Date: 13-09-2017

- Review completed: 05-11-2017;

- Accepted Date: 22-11-2017

DOI : 10.5530/pj.2018.3.72

Article Available online

http://www.phcogj.com/v10/i3

\section{Copyright}

(C) 2018 Phcog.Net. This is an openaccess article distributed under the terms of the Creative Commons Attribution 4.0 International license.

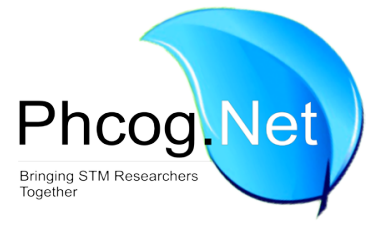

\begin{abstract}
Back ground: High-performance Liquid Chromatography is one of the major analytical techniques used in the quality control of phytochemicals. Objective: This research article presents the development of HPLC method to detect and quantify the major marker components, kaempferol, and quercetin from four plant species. Materials and Methods: HPLC method was developed for the qualitative and quantitative analysis of plant extracts by using orthophosphoric acid and methanol (95:5) at $370 \mathrm{~nm}$ for kaempferol, methanol and orthophosphoric acid (60:40) at $262 \mathrm{~nm}$ for quercetin. Results: Kaempferol was detected from the hydro alcoholic extracts of Talinum portulacifolium leaves (RT 13.720, concentration $1.08 \mathrm{mg} / \mathrm{ml}$ ) and flowers of Gomphrena serrata (RT 13.758, concentration $2.13 \mathrm{mg} / \mathrm{ml}$ ). Kaempferol was reported for the first time from Gomphrena serrata. Quercetin was separated and identified from the hydro alcoholic extracts Alternanthera sessilis stems (RT 6.503, concentration $0.01 \mathrm{mg} / \mathrm{ml}$ ). The hydroalcoholic extract of Euphorbia heterophylla stems (RT 6.588, concentration $0.01 \mathrm{mg} / \mathrm{ml}$ ) was also evaluated for the presence of quercetin. Conclusion: The method developed is very useful tool for qualifying and quantifying the plant specimens as well as their extracts.
\end{abstract}

Key words: Marker, Kaempferol, Quercetin, HPLC, Quality control, Plant specimens, Extracts.

\section{INTRODUCTION}

Phytomedicines, refer to the medicinal products from various parts of plants that can be used to promote health and treat diseases. Despite the major advances in the modern medicine, the development of new drugs from natural products is still considered important. Since 1980, the World Health Organization has been encouraging countries to identify and exploit traditional medicine and phytotherapy. ${ }^{1}$ There have always been concerns about the inconsistent composition of herbal medicines and occasional cases of intoxication by adulterants and/or toxic components. The development of phytotherapeutic products is dependent on their standardization, to guarantee not only the authenticity of the plant extract but also to enable a dose related use. Quality control of herbal medicines aims to ensure their consistency, safety, and efficacy. ${ }^{2}$ Chromatographic methods have been recommended for the quality control of phytotherapeutic products with many advantages over other methods. ${ }^{3,45}$ Chemical fingerprinting has been a powerful tool for the quality control of herbal medicines. A chemical fingerprint is a unique pattern that indicates the presence of multiple chemical markers existing in a sample. In the process, technologies such as high- performance liquid chromatography (HPLC), high-performance capillary electrophoresis (HPCE), and liquid chromatography-mass spectrometry (LC-MS) are often used. ${ }^{6}$ Chemical fingerprinting by HPLC is simple, sensitive and in expensive, and has been widely used in the pharmaceutical field. A chemical marker may or may not have the therapeutic activity, but the quantity of chemical marker can be an indicator of the quality of herbal medicine, including authentication of species or substitutes, optimization of extraction and purification methodology, structure and purity determination. All markers may contribute to the evaluation, standardization and safety analysis of herbal medicines. ${ }^{7}$

The genus Talinum comprises about 50 species. ${ }^{8,9}$ Leaves of the plant Talinum portulacifolium Forsk. Belonging to family Portulacaceae, possess antidiabetic and aphrodisiac properties. ${ }^{10}$ The plant was used to treat arthritis, backache, and diarrhea. ${ }^{11}$ It is also used as a medicine for constipation and ulcer. ${ }^{12}$ Previous chemical studies on this species reported that leaves and stem extracts contain quercetin, tannins, phosphates, urea, and various minerals with a 
larger amount of magnesium. ${ }^{13}$ Antiasthmatic studies on hydro alcoholic and acetone extracts of the plant along with GC-MS (Gas chromatography mass spectrometry) analysis of chloroform fraction from the acetone extract of leaves revealed the presence of major phytoconstituents namely, methoxy-bis(cyclopentadiene),5,10-dihexyl-5,10-dihydroindolo[3,2-b] indole-2,7-dicarbaldehyde, and 1,2-bis[3,4-dimethoxy benzyl]-1,2-bis (methoxy methyl) ethane. ${ }^{14}$ HPLC analysis of quercetin was carried out on leaf and stem methanolic extracts. ${ }^{13}$ Kaempferol was isolated from chloroform and methanolic extracts of leaves. ${ }^{15}$ There were no reports available on the HPLC identification and quantification of kaempferol from this plant species.

Gomphrena serrata Linn, Amaranthaceae, is a road side herb grown in temperate regions of the world. Gomphrena species are employed in the treatment of bronchial asthma, diarrhea, and fever, and as an analgesic, tonic, or carminative. ${ }^{16}$ This species showed antimalarial and diuretic activities. ${ }^{17,18}$ Oleuropein was isolated from the chloroform extract of the whole plant. ${ }^{19}$ GC-MS analysis of chloroform fraction showed the presence of 30 bioactive compounds. ${ }^{20}$ There is little phytochemical and pharmacological screening report on this species. ${ }^{16,17,18,19,20,21}$ The phytochemical review on Gomphrena serrata indicates that there were no reports available for the presence and detection of kaempferol from the plant species. Kaempferol was reported for the first time from the plant species.

Alternanthera sessilis Linn. Amaranthaceae, is used as a vegetable in Asia, traditionally used in skin diseases, to cure wounds and as an antidote. The plant is reported for various pharmacological activities like haematinic, ${ }^{22}$ antioxidant, ${ }^{23}$ anti-inflammatory, ${ }^{24}$ hepatoprotective, ${ }^{25}$ antiulcer, ${ }^{26}$ antimicrobial, ${ }^{27}$ and wound healing. ${ }^{28}$ It was reported to contain $\beta$ - carotene, ${ }^{29}$ lupeol, ${ }^{30} \alpha$ and $\beta$ spinasterol, ${ }^{31} \beta$-sitosterol, stigmasterol, ${ }^{32}$ and campesterol. ${ }^{29}$ Antiasthmatic studies were performed on the hydro alcoholic and acetone extracts of stems along with a GC-MS analysis of chloroform fraction of acetone extract of stems, depicted following major phytoconstituents, methoxy-bis (cyclopentadiene), 5,10-dihexyl5,10-dihydroindolo[3,2-b]indole-2,7-dicarbaldehyde and 1,2-bis[3,4dimethoxy benzyl]-1,2-bis (methoxymethyl) ethane respectively. ${ }^{33}$ HPTLC finger printing analysis was carried out for the detection and quantification of gallic acid in methanolic extract of leaves. ${ }^{34}$ HPLC finger printing analysis was performed for the detection and quantification of polyphenols catechin, rutin, ellagic acid and quercetin in the ethanolic extract of the whole plant. ${ }^{35}$ There were no reports available on the HPLC analysis of quercetin on stems of the plant species.

Euphorbia heterophylla L, Euphorbiaceae, is a branched shrub belonging to the family Euphorbiaceae, widely distributed in the South Asian continent. The plant was reported for activities like antimicrobial and anticancer activity, ${ }^{36}$ hepatoprotective activity, ${ }^{37}$ anti-diabetic activity, ${ }^{38}$ effect of plant extract on kidney, liver and pancreatic functions was reported. ${ }^{39}$ Stigmasterol and 4-hydroxy benzoic acid were isolated from the leaf extracts showed good activity against xanthine oxidase enzymes, ${ }^{40}$ diterpenoids were isolated from roots. ${ }^{41}$ The leaves of Euphorbia heterophylla were reported to contain quercetin. ${ }^{42}$ There were no reports of HPLC analysis on quercetin from this species.

The aim of the present study was to detect and quantify the phytochemical marker compounds kaempferol from hydro alcoholic extracts of Talinum portulacifolium leaves and Gomphrena serrata flowers followed by quercetin from the hydro alcoholic extracts of and Alternanthera sessilis stems and Euphorbia heterophylla stems by HPLC analysis respectively. The literature review presents no reports available on the HPLC determination of major photo chemicals kaempferol and quercetin present in the plant extracts, hence an effort was made to explore them for standardization of medicinal herbal extracts.

\section{MATERIALS AND METHODS}

\section{Collection of plant material}

The plant materials were collected from local grounds of Prasadampadu, and Enikepadu coordinates $16^{\circ} 32^{\prime} 45^{\prime \prime} \mathrm{N} 80^{\circ} 34^{\prime} 12^{\prime \prime} \mathrm{E}$ of Vijayawada rural region, Krishna District, Andhra Pradesh, India. The plant specimens were identified and authenticated by Dr. P. Satya Narayana Raju, plant taxonomist, Department of Botany and Microbiology, Acharya Nagarjuna University (ANU), Guntur (District), Andhra Pradesh, India. Voucher specimens 001/VIPW- Gomphrena serrata, 002/VIPW- Alternanthera sessilis, 003/VIPW- Euphorbia heterophylla, 004/VIPW- Talinum portulacifolium were deposited in the department of Pharmacognosy, Vijaya Institute of Pharmaceutical Sciences for Women, Enikepadu, Vijayawada for future reference. The plant pictures were depicted [Figure 1, Figure 2, Figure 3, Figure 4] respectively.

\section{Preparation of the extract}

The plant parts were shade dried, powdered coarsely and extracted using methanol and water (50:50) by Soxhlet apparatus. The extracts were dried using vacuum evaporator. They were preserved in refrigerator till use.
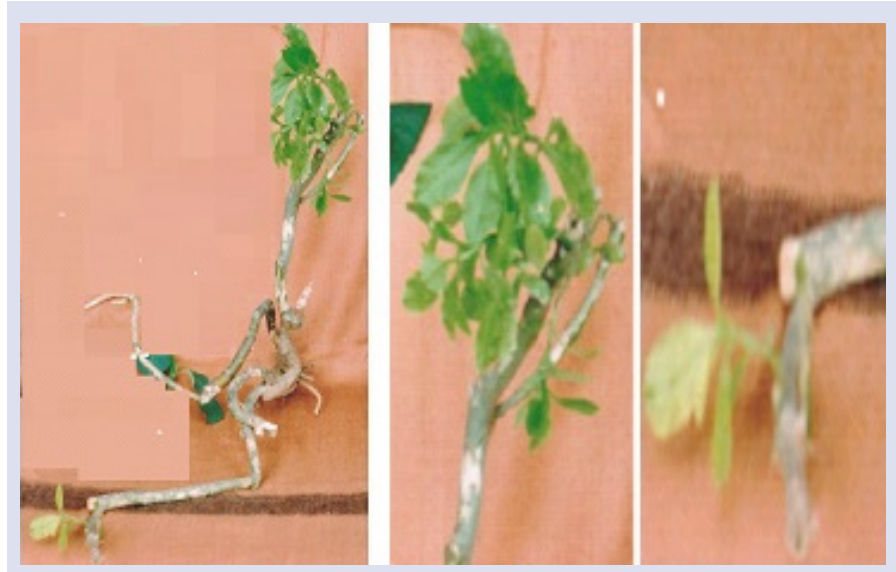

Figure 1: Talinum portulacifolium plant and leaves.
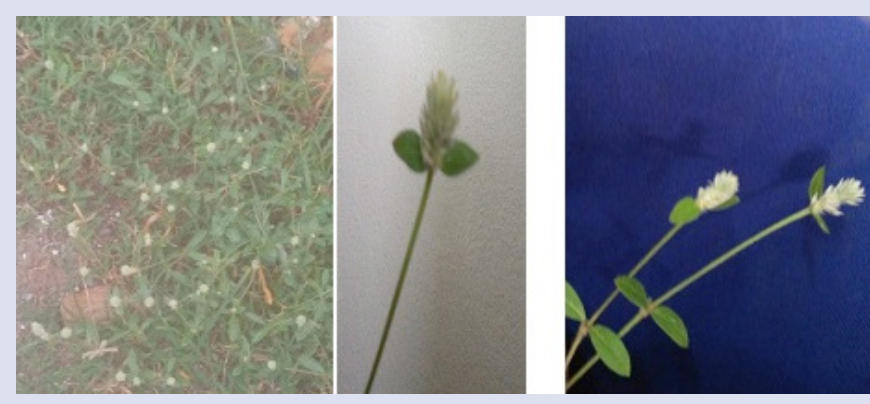

Figure 2: Gomphrena serrata plant and flower
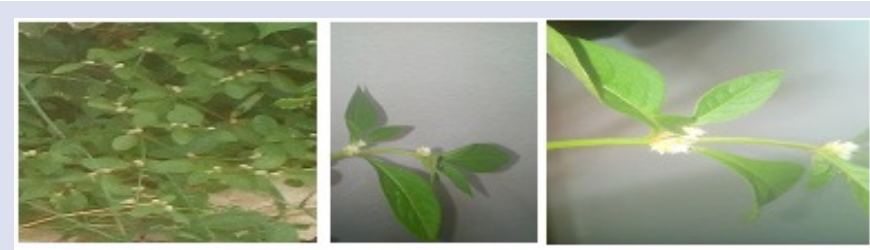

Figure 3: Alternanthera sessilis plant and twig 


\section{Chemicals and Reagents}

All the chemicals and reagents used were of analytical grade, purchased from Sigma-Aldrich Chemical Co.

\section{Thin layer chromatography}

Qualitative analysis of kaempferol and quercetin for the plant extracts was carried out by TLC (Thin layer chromatography) on silica gel using acetic acid, methanol, and water in the ratio of 5:25:75. The spots observed were studied under UV and $\mathrm{R}_{\mathrm{f}}$ values were calculated. ${ }^{43}$

\section{Instrument and chromatographic conditions}

HPLC analysis was performed on the Shimadzu LC-20 system (Shimadzu, Kyoto, Japan) equipped with a pump (LC-20AD), auto sampler (SIL-20A), and column oven and diode array detector (SPD-M20A). The output signal of the detector was recorded using LC Solution software. The separation was executed on a YMC-Pack ODS-A C18 $(250 \mathrm{~mm} \times 4.6 \mathrm{~mm}, 5 \mu \mathrm{m})$.

\section{Quantification of kaempferol}

Kaempferol was identified and quantified from leaf hydro alcoholic extracts of Talinum portulacifolium coded as TPLHAE and the flower hydro alcoholic extracts of Gomphrena serrata, coded as GSFHAE respectively. The standard sample kaempferol was coded as STDKF. The result was given [Table 2], HPLC chromatograms for STDKF, TPLHAE and GSFHAE were produced [Figure 5, Figure 6 and Figure 7] respectively.

\section{Preparation of mobile phase}

The mobile phase (A) was composed of $0.136 \mathrm{~g}$ of anhydrous potassium dihydrogen orthophosphate was dissolved in $900 \mathrm{ml}$ of HPLC grade water and $0.5 \mathrm{ml}$ of orthophosphoric acid was added. The volume was made up to $1000 \mathrm{ml}$. The mobile phase (B) was composed of acetonitrile. The mobile phase $(\mathrm{A})$ and $(\mathrm{B})$ were run with gradient elution system at $0.01-18.0 \mathrm{~min}, 95 \%(\mathrm{~A}), 5.0 \%(\mathrm{~B}) ; 18.0-25.0 \mathrm{~min}, 55.0 \%(\mathrm{~A}), 45.0 \%(\mathrm{~B})$; 25.0-28.0 min, $20.0 \%$ (A), $80.0 \%$ (B); $28.0-35.0 \mathrm{~min}, 20 \%$ (A), $80 \%$ (B); 35.0- $40.0 \mathrm{~min}, 55.0 \%$ (A), 45\% (B); 40.0-45.0 min, $95.0 \%$ (A), 5\% (B) and $45 \min 95 \%$ (A), 5\% (B) respectively [Table 1]. Both the mobile phases were run at a flow rate of $1.5 \mathrm{ml} / \mathrm{min}$. The injection volume was $20 \mu \mathrm{l}$. The detection UV length was set at $370 \mathrm{~nm}$. The column temperature was maintained at $35^{\circ} \mathrm{C}$.

\section{Preparation of standard solution}

The standard stock solution was prepared by dissolving $5 \mathrm{mg}$ of quercetin in $1 \mathrm{ml}$ mobile phase. The standard working solution was prepared by taking $4 \mu \mathrm{l}$ from stock and made up to $1 \mathrm{ml}$ by mobile phase to get $20 \mu \mathrm{g} / \mathrm{ml}$. The stock and working solutions were stored at $4^{\circ} \mathrm{C}$.

\section{Preparation of sample solution}

$1000 \mathrm{mg}$ of extract was dissolved in $10 \mathrm{ml}$ methanol using a standard volumetric flask, sonicated for $10 \mathrm{~min}$, and the sample was filtered before injection. ${ }^{44,45}$

\section{Quantification of quercetin}

Quercetin was identified and quantified from the stem hydro alcoholic extracts of Euphorbia heterophylla coded as EHSHAE and Alternanthera sessilis coded as ASSHAE. The standard sample quercetin was coded as STDQU. The result was produced [Table 4]. HPLC chromatograms were given [Figure 8, Figure 9, Figure10] respectively.

\section{Preparation of mobile phase}

The mobile phase (A) was composed of $0.1 \%$ orthophosphoric acid in water. Mobile phase (B) was composed of methanol. The mobile phase (A) and (B) were run with gradient elution system at 0.01-2.5 min, 90\% (A), $10 \%$ (B); $2.5-5.0$ min $75 \%$ (A), 25\% (B); 5.0-7.5 min 40\% (A), $60 \%$ (B); 7.5-10.00 $\min 90 \%$ (A), 10\% (B) respectively (Table 3 ). The mobile phase was run at a flow rate of $1.1 \mathrm{ml} / \mathrm{min}$. The injection volume was $20 \mu \mathrm{l}$. The detector wave length was $262 \mathrm{~nm}$. The column temperature was maintained at $35^{\circ} \mathrm{C}$.

\section{Preparation of standard solution}

The standard stock solution was prepared by dissolving $5 \mathrm{mg}$ of quercetin in $1 \mathrm{ml}$ mobile phase. The standard working solution was prepared by taking $0.2 \mathrm{ml}$ from stock solution and was made up to $1 \mathrm{ml}$ by mobile phase to get $1000 \mu \mathrm{g} / \mathrm{ml}$.

\section{Preparation of sample solution}

$5 \mathrm{mg}$ of extract was dissolved in $10 \mathrm{ml}$ mobile phase. It was sonicated for 10 min and filtered before injection. ${ }^{44,45}$

\section{RESULTS AND DISCUSSION}

Herbal drug standardization comprises total information on the composition of all herbals including analytical operations for identification and assay of therapeutic and inactive principles. Chromatographic finger printing of herbal medicines is utilized for the authenticity and quality control of herbal medicines, which has become the most important tool for quality control of traditional herbal medicines (HPLC). Further, the combination of qualitative fingerprinting and quantitative analysis is a novel and rational method to address the key issues of quality control of herbal medicines. ${ }^{46}$ HPLC spectra showed the presence of kaempferol and quercetin in the plant extracts. The structures for kaempferol and quercetin were given [Figure 11]. ${ }^{47}$

In the present study, two of the phytochemicals namely kaempferol and quercetin were analyzed by TLC and HPLC methods. The $\mathrm{R}_{\mathrm{f}}$ values noted for kaempferol was 0.47 and for quercetin, 0.62 after examining the yellow fluorescent spots under UV. The HPLC method was developed for the qualitative and quantitative estimation of kaempferol from hydro

\begin{tabular}{ccc}
$\begin{array}{l}\text { Table 1: Gradient conditions for mobile phase run during quantifica- } \\
\text { tion of Kaempferol }\end{array}$ & \multicolumn{3}{c}{ Acetonitrile } \\
\hline Time (min) & $\begin{array}{r}\text { Buffer concentration } \\
\text { (Solvent A) }\end{array}$ & $\begin{array}{c}\text { Aoncentration } \\
\text { (Solvent B) }\end{array}$ \\
\hline 0.01 & 95.0 & 5.0 \\
18.0 & 55.0 & 45.0 \\
25.0 & 20.0 & 80.0 \\
28.0 & 20.0 & 80.0 \\
35.0 & 55.0 & 45.0 \\
40.0 & 95.0 & 5.0 \\
45.0 & 95.0 & 5.0 \\
\hline
\end{tabular}

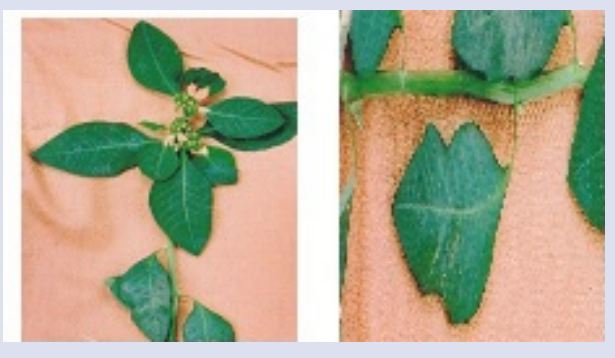

Figure 4: Euphorbia heterophylla plant and twig 


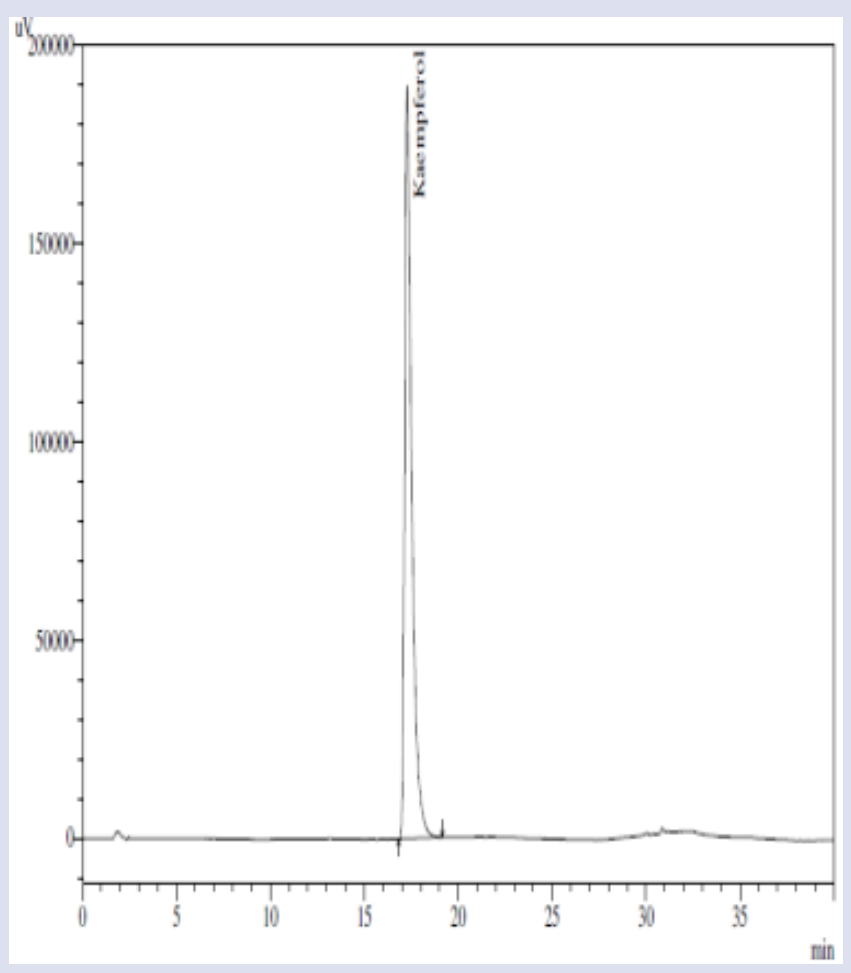

Figure 5: HPLC chromatogram indicating detection of kaempferol in STDKF

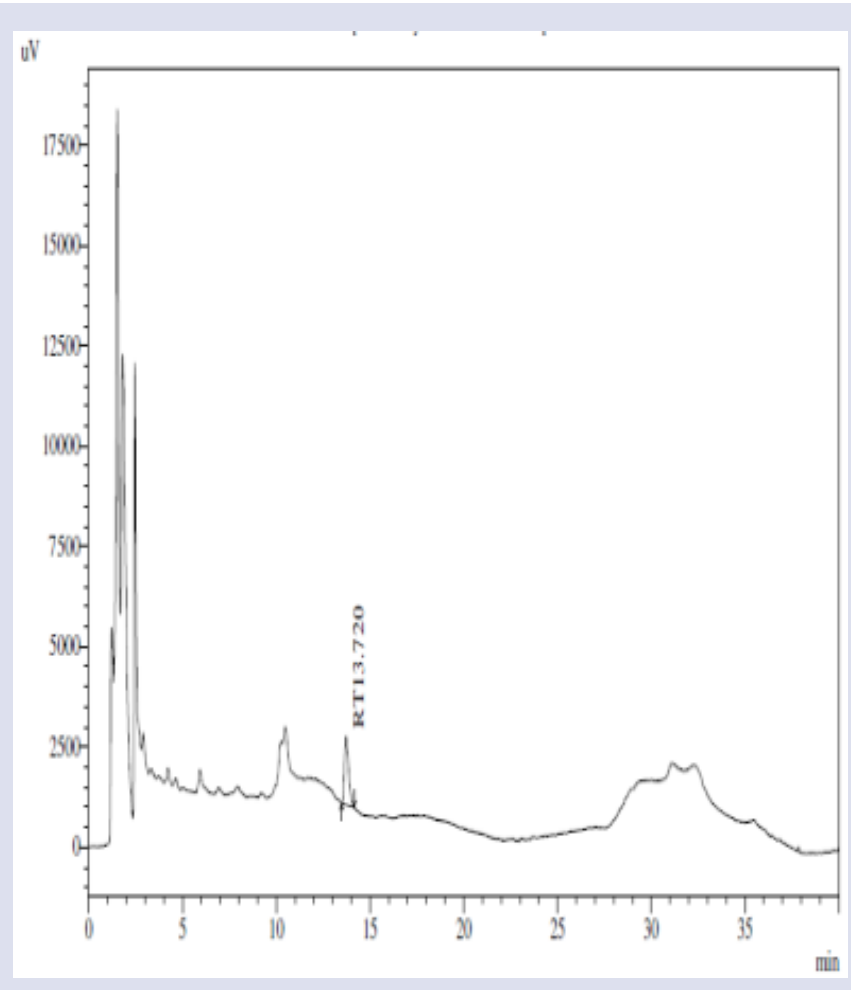

Figure 6: HPLC chromatogram indicating detection of kaempferol in TPLHAE

Table 2: Quantification of Kaempferol in STDKF, TPLHAE, and GSFHAE

\begin{tabular}{ccccccc} 
Sample & $\begin{array}{c}\text { Concentration } \\
\text { injected } \\
(\mathbf{m g} / \mathrm{ml})\end{array}$ & $\begin{array}{c}\text { Retention time } \\
\text { (minutes) }\end{array}$ & $\begin{array}{c}\text { Name of the } \\
\text { compound }\end{array}$ & Area & $\begin{array}{c}\text { \% } \\
\text { peak area }\end{array}$ & $\begin{array}{c}\text { Concentration } \\
\text { detected } \\
(\mathbf{m g} / \mathrm{ml})\end{array}$ \\
\hline STDKF & 0.02 & 17.276 & Kaempferol & 4943748 & 99.4 & 0.02 \\
TPLHAE & 100 & 13.720 & Kaempferol & 26819 & 0.5 & 1.08 \\
GSFHAE & 100 & 13.758 & Kaempferol & 5281 & 0.1 & 2.13 \\
\hline
\end{tabular}

alcoholic herbal extracts of Talinum portulacifolium, Gomphrena serrata and quercetin from Euphorbia heterophylla and Alternanthera sessilis respectively. Retention time was used as a parameter for analysis of results. Many studies have suggested that flavonoid, kaempferol is well-known for its anti-inflammatory, antiallergic, antithrombotic, hepatoprotective, antispasmodic and anticancer properties. ${ }^{48}$ Kaempferol is a natural flavonol, a type of flavonoid, that has been isolated from tea, broccoli, Delphinium, Witch-hazel, grapefruit, cabbage, beans, endive, leek, tomato, strawberries, grapes, Brussels sprouts, apples and other plant sources. ${ }^{49}$

HPLC spectra of STDKF for kaempferol showed a peak at retention time of $17.276 \mathrm{~min}$, TPLHAE at $13.720 \mathrm{~min}$ and $13.758 \mathrm{~min}$ was observed for GSFHAE respectively [Figure1, Figure 2 and Figure 3]. The mobile phase consists of solvent (A): solvent (B) (95:5 V/V) [Table 1]. Concentration of kaempferol present in TPLHAE at $100 \mathrm{mg} / \mathrm{ml}$ was found to be $1.08 \mathrm{mg} / \mathrm{ml}$. The concentration of kaempferol in GSFHAE was found to be $2.13 \mathrm{mg} / \mathrm{ml}$ [Table 2]. Kaempferol was present in a good amount in both the plant extracts TPLHAE and GSFHAE when compared to the methanolic extract of Tridox procumbens $(0.816 \mathrm{mg} / \mathrm{ml}){ }^{45}$
The quality control study conducted in the present investigation for Talinum portulacifolium leaves is well supported by the total phenolic content of plant leaf extracts expressed as equivalent to $\mu \mathrm{g}$ of gallic acid/100 gm dry weight of plant material for chloroform extract $39 \mu$ g, ethyl acetate extract $30 \mu \mathrm{g}$, methanolic extract $24.5 \mu \mathrm{g}$ and aqueous extract $20 \mu \mathrm{g} .{ }^{50}$ The total phenolic content $9000 \mathrm{mg} \mathrm{GAE} / 100 \mathrm{gm}$ (Gallic acid equivalent), total flavonol content $1840 \mathrm{mg}$ GAE/100gm found in the methanolic extract of leaves whereas stem extracts showed less amount of phenolics $2880 \mathrm{mg}$ GAE/100gm and flavonols $360 \mathrm{mg}$ GAE/100gm respectively (Adithya 2012). The plant leaf extracts were studied for mineral content, sodium $365 \mathrm{mg} / \mathrm{Kg}$, showed more potassium mineral content $514 \mathrm{mg} / \mathrm{Kg}$, calcium $105 \mathrm{mg} / \mathrm{Kg}$, phosphorous $367 \mathrm{mg} / \mathrm{Kg}$. HPLC analysis of quercetin showed 3:30 $\mathrm{min} / \mathrm{sec}$ RT with concentration $0.15 \mathrm{mg} / \mathrm{Kg}$ in leaf extract and very less amount $0.08 \mathrm{mg} / \mathrm{Kg}$ in the stem extracts. ${ }^{13}$ Leaves possess the highest amount of phenolics, flavonoids, and flavonols. Total phenolic content of hexane extract of leaves was found to be $61 \mathrm{mg}$ GAE /gm, ethanol extract $100 \mathrm{mg}$ GAE /gm and aqueous extract possess more amount of phenolics $114 \mathrm{mg}$ GAE /gm followed by extractive values $6.7 \%, 8.3 \%$ and $21 \%$. TLC was performed using hexane and ethyl acetate (5:5) and methanol and acetonitrile (7:3), yellow spots developed 


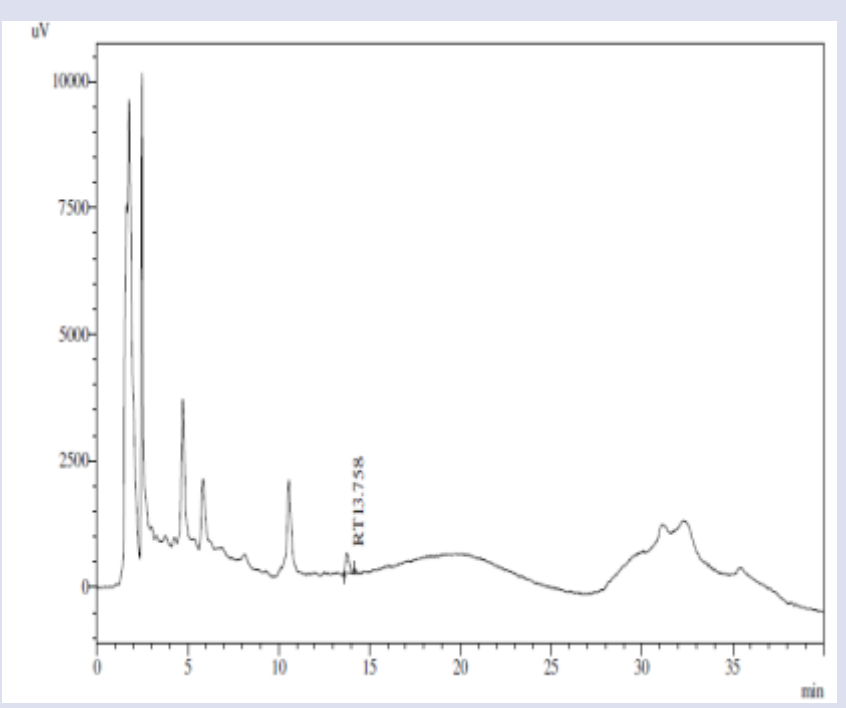

Figure 7: HPLC chromatogram indicating detection of kaempferol in GSFHAE

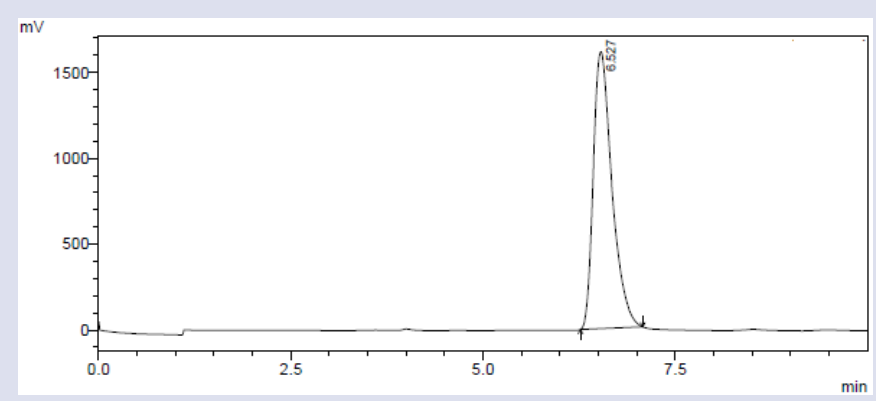

Figure 8: HPLC chromatogram indicating detection of quercetin in STDQU

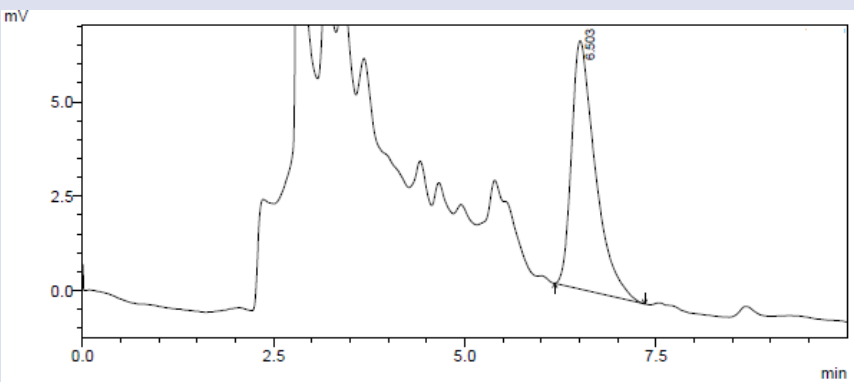

Figure 9: HPLC chromatogram indicating detection of quercetin in ALSHAE

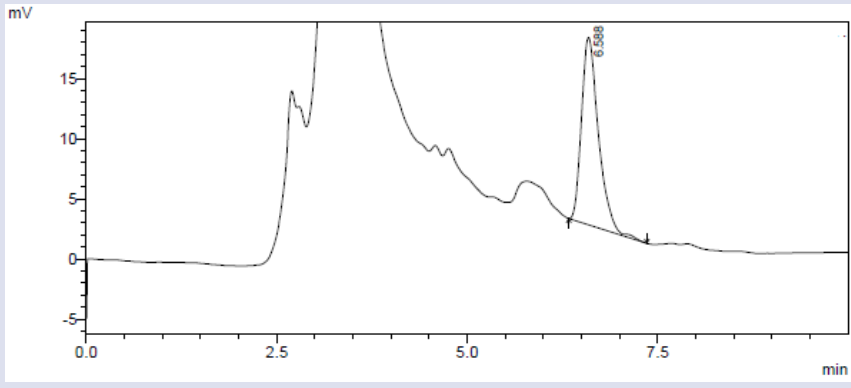

Figure 10: HPLC chromatogram indicating detection of quercetin in EHSHAE<smiles></smiles>

Figure 11: Structures of kaempferol and quercetin

Table 3: Gradient conditions for mobile phase run during quantification of quercetin

\begin{tabular}{ccc}
\hline Time $(\min )$ & $\begin{array}{c}\text { Ortho phosphoric acid } \\
\text { concentration (Solvent } \\
\text { A) }\end{array}$ & $\begin{array}{c}\text { Methanol } \\
\text { concentration } \\
\text { (Solvent B) }\end{array}$ \\
\hline 0.01 & 90 & 10 \\
2.5 & 75 & 25 \\
5.0 & 40 & 60 \\
7.5 & 80 & 20 \\
10.00 & 90 & 10 \\
\hline
\end{tabular}

\begin{tabular}{cccccccc|}
\hline \multicolumn{2}{l}{ Table 4: Quantification of quercetin in STDQU, EHSHAE, and ALSHAE } & & & & \\
Sample & $\begin{array}{c}\text { Concentration } \\
\text { injected }(\mathrm{mg} / \mathrm{ml})\end{array}$ & $\begin{array}{c}\text { Retention time } \\
(\mathrm{min})\end{array}$ & $\begin{array}{c}\text { Name of the } \\
\text { compound }\end{array}$ & Area & $\begin{array}{c}\% \text { Peak } \\
\text { area }\end{array}$ & $\begin{array}{c}\text { Concentration detected } \\
(\mathrm{mg} / \mathrm{ml})\end{array}$ \\
STDQU & 1 & 6.527 & Quercetin & 27251716 & 98 & 1 \\
ASHRAE & 0.5 & 6.503 & Quercetin & 142247 & 1.0 & 0.01 \\
EHSHAE & 0.5 & 6.588 & Quercetin & 240927 & 1.7 & 0.01
\end{tabular}


against purple background indicating antioxidant compounds after spraying with DPPH reagent. ${ }^{10}$ Luteolin and kaempferol were isolated ${ }^{15}$ from the methanolic extract of leaves, showed the presence of luteolin and kaempferol by TLC, IR (Infrared) Mass and NMR (Nuclear magnetic resonance) spectral studies. ${ }^{15}$

Partial support for the standardization studies of Gomphrena serrata can be attributed to the morphological description of various parts of the plant, often the species is confused with Gomphrena celoisoides, which can be differentiated by oblanceolate, acute apex leaf being present in G. serrata while oblong obovate, obtuse apex leaf can be seen in G. celoisoides. ${ }^{51}$

HPLC spectra of STDQU for quercetin showed a peak at retention time of $6.527 \mathrm{~min}$, and $6.503 \mathrm{~min}$ and spectra of EHSHAE at $6.588 \mathrm{~min}$ observed for ALSHAE respectively [Figure 8, Figure 9 and Figure 10]. The mobile phase consists of methanol: $0.1 \%$ orthophosphoric acid in water $(60: 40 \mathrm{v} / \mathrm{v})$. Percentage of quercetin present in the herbal extract was calculated. The quantified amount for ALSHAE was found to be $0.01 \mathrm{mg} / \mathrm{ml}$ of plant extract. The quantified amount was found to be $0.01 \mathrm{mg} / \mathrm{ml}$ for EHSHAE [Table 4].

Quercetin is present in different parts of plants not only as aglycones but also as glycosides and is known to impart profuse color to the fruits, flowers, leafy parts etc. It is reported to display anti-histamine, anti-cancer as also anti-inflammatory activities which mostly follow its antioxidant traits. The dietary sources of quercetin include citrus fruits, apples, onions, parsley, sage, tea and red wine. In fact, onion (Allium cepa L) is the richest source of quercetin $(2.60 \mathrm{mg} / \mathrm{gm})$ whereas a very good amount of this flavonol was found in hydro alcoholic extracts of ALSHAE $0.01 \mathrm{mg} / \mathrm{ml}$ and EHSHAE $0.01 \mathrm{mg} / \mathrm{ml}$. An appreciable amount of quercetin, detected in the extracts of ALSHAE and EHAHAE were comparable to the same in apple $(0.021 \mathrm{mg} / \mathrm{gm})$, lettuce $(0.011 \mathrm{mg} / \mathrm{gm})$ and tomato $(0.055 \mathrm{mg} / \mathrm{gm}){ }^{44}$

Additional support to the current study can be obtained from the concentration of gallic acid by HPTLC analysis for the methanolic extract of leaves of Alternanthera sessilis was found to be $8.022 \mu \mathrm{g} / \mathrm{ml}$ which would be useful in establishing the standardization parameters and act as a reference in detecting adulteration or substitution (Rajiv Gupta 2016). HPLC analysis of various polyphenols, catechin, rutin, ellagic acid and quercetin found at $117.72,490.74,3007.26$ and $13.85 \mathrm{mg} / 100 \mathrm{gm}$ of a dry extract from ethanolic extract of the whole plant was carried out. ${ }^{35}$ Further, morphological and microscopical descriptions of various parts of the plant also contribute to the current experimentation. ${ }^{55}$

The scientific data reported on quality control studies of Euphorbia heterophylla includes the plant species Euphorbia heterophylla is confused with Euphorbia cyathophora. They can be identified through plant characteristics. E cyathophora is distinguished by the presence of unstalked ovary where the stalked ovary is seen in E.heterophylla. ${ }^{52}$ The percentage of total alkaloids $2.9 \mu \mathrm{g} / \mathrm{g}$, saponins $3.72 \mu \mathrm{g} / \mathrm{g}$, saponins, $0.17 \mu \mathrm{g} / \mathrm{g}$ flavonoids, $0.81 \mu \mathrm{g} / \mathrm{g}$ tannins was determined. ${ }^{53}$ Quantification of primary metabolites were studied, where total carbohydrate was found to be $10.29 \mathrm{mg} / \mathrm{g}$, total protein $7.43 \mathrm{mg} / \mathrm{g}$, fat $3.5 \mathrm{mg} / \mathrm{g}$ followed by total phenolic content $8.26 \mathrm{mg} / \mathrm{g}$ and ascorbic acid $1.14 \%$ from the aqueous extract of leaves of the plant. The standardization parameters favoring the quality control of aqueous extract of leaves, studied were moisture content $11.79 \%$ and ash value $2.57 \%$, moreover, the plant was supposed to possess high carbohydrate content with more number of reducing sugars and rich nutrient status. ${ }^{54}$ The retention times of both kaempferol and quercetin detected in the plant extracts were comparable to standard drugs. The developed method offers rapid detection and quantification of kaempferol and quercetin in plant extracts and therefore can be used as a reference for carrying out the standardization studies.

\section{CONCLUSION}

The study confirmed the presence of biologically and pharmacologically important flavonoids as markers, kaempferol, and quercetin in a quantifiable amount in the plant extracts. The developed method has enabled rapid analysis of two flavonoids with marked retention time. The results of the study can be used for developing the quality control profile, qualitative and quantitative analysis of extracts and other plant species containing these two flavonoids.

\section{ACKNOWLEDGEMENT}

Authors are grateful to Radiant research laboratories, Bangalore, Karnataka, India, Jawaharlal Nehru Technological University, Kakinada, East Godavari (Dt.), A.P., India, Vijaya Institute of Pharmaceutical Sciences for Women,, Enikepadu, Vijayawada, Krishna (Dt.), A.P., India, Nirmala College of Pharmacy, Atmakur, Mangalagiri, Guntur (Dt.), A.P., India, Department of Pharmaceutics, Acharya Nagarjuna University, Nagarjuna Nagar, Guntur (Dt.), A.P., India for their kind encouragement and support.

\section{CONFLICT OF INTEREST}

The authors declare no conflict of interest.

\section{ABBREVIATION USED}

HPLC: High performance liquid chromatography; HPCE: High performance capillary electrophoresis; LC-MS: Liquid chromatographymass spectrometry; GC-MS: Gas chromatography-Mass spectrometry; HPTLC: High performance thin layer chromatography; ANU: Acharya Nagarjuna University; TPLHAE: Talinum portulacifoliun hydro alcoholic extract; GSFHAE: Gomphrena serrata hydro alcoholic extract; STDKF: Standard Kaempferol; EHSHAE: Euphorbia heterophylla hydro alcoholic extract; ASSHAE: Alternanthera sessilis hydro alcoholic extract; STDQU: Standard quercetin; Rf: Retention factor; TLC: Thin layer Chromatography; UV: Ultra violet; GAE: Gallic acid Equivalent; DPPH: Diphenyl picryl hydrazyl; IR: Infrared; NMR: Nuclear magnetic Resonance; RT: Retention time; Kg: Kilogram; $\mu$ g: Microgrm; mg: Milligram; ml: Milli litre; min: Minutes; gm: Gram; ${ }^{0} \mathbf{C}$ : Degree Celsius; nm: Nanometreas; \%: Percentage.

\section{REFERENCES}

1. Akerele-Curare O. Medicinal plants and primary health care: An agenda for action. Fitoterapia. 1988; 59:355.

2. World Health Organization, WHO traditional medicine strategy 2002-2005 Geneva: WHO.

3. Gyéresi A, Kelemen H, Kata M. Modern TLC. J. Planar Chromatogr.1997; 10 (3):172-177

4. Kinghorn AD, EK Yuny. Chromatographic/Chromatographic Spectroscopic Combination Methods for the Analysis of Botanical Drugs. Drug Inf. J. 1998; 32:487.

5. Celeghini RMS, Villegas JHY, Lanças FM.Extraction and quantitative HPLC analysis of coumarin in hydro alcoholic extracts of Mikania glomerate spring. J. Braz. Chem.Soc. 2001; 12(6):706-709

6. Qin KM, Cai H, Zhang L, Shi Y, Li P, Cai BC. Chemical constituents and effective substances of traditional Chinese medicinal formula. Prog Chem. 2010 22:2436-49.

7. Lin $B Q$, Ji H, Li P, Jiang Y, Fang W: Selective antagonism activity of alkaloids from Bulbs Fritillariae at muscarinic receptors: functional studies. Eur J Pharmacol. 2006; 551:125-30

8. Grubben GJ, Denton OA. Plant Resources of Tropical Africa: Vegetables. Wageningen: PROTA Foundation; 2004. p. 519.

9. Pullaiah T. Encyclopedia of World Medicinal Plants. Vol. 5. New Delhi: Regency Publications; 2006. p. 2358

10. Babu KR, Vinay K, Sameena SK, Prasad SV, Swapna S, Rao AC. Antihyperglycemic and antioxidant effects of Talinum portulacifolium leaf extracts in streptozotocin diabetic rats: A dose-dependent study. Pharmacogn Mag. 2009; 5:1-10.

11. Kiring JW. A survey of traditional health remedies used by the Maasai of Southern Kaijiado district, Kenya. Ethnobot Res Appl. 2006; 4:61-73. 
12. Thangavel K, Maridass M, Sasikala M, Ganesan V. In vitro micro propagation of Talinum portulacifolium L. Through axillary bud culture. Ethnobot Leaflets. 2008; 12:413-8.

13. Aditya ES, Sasikumar JM, Kumar K, Lakshmi MS, Christabel PH. In vitro antioxidant activity, mineral content and HPLC analysis of Talinum portulacifolium (Forssk.) Asch. ex Schweinf. Leaf and stem. Int J Pharm Sci. 2012; 4:423-9.

14. Mamillapalli Vani, S. K. Abdul Rahaman, Avula Prameela Rani In vitro, in vivo Anti-Asthmatic Studies of Talinum portulacifolium F. Asian J. Pharm. 2017; $11(2)$ :S289.

15. Sunil J, Nath MS, Raja S, Vinatha B. Phytochemical studies on Talinum portulacifolium (Forsk). Sci J Pharm. 2010; 1:1-4.

16. CCJ Vieira, H Mercier, EP Chu, RCL Figueiredo-Ribeiro. Biotechnology in Agriculture and Forestry, Springer-Verlag, Berlin, 1994; 257-270.

17. MC Gessler; MH Nkunya; LB Mwasumbi; MHeinrich; M Tanner. Acta Tropica.1994; 56:65-77.

18. Dhawan BN, Patnaik GK, Rastogi RP, Singh KK, Tandon JS. Indian J. Exp. Biol. 1977; 15:208-219.

19. Babu G, Anju P, Biju CR, Raja panda R.Phytochemical screening of Gomphrena serrata. L.J.Chem.Pharm.Res. 2012; 4(7):3396-3397.

20. Mamillapalli Vani, S. K. Abdul Rahaman, Avula Prameela Rani Phytochemical Constituents of Gomphrena Serrata L. Int. J. Pharm. Biol. Sci. 2017; 6(9):1803-1815.

21. Banerji A, Chintalwar GJ, Joshi NK, Chadha MS. Phytochem. 1971;10:2225-26.

22. Erna C Arollado, Marina O Osi. Hematinic activity of Alternanthera Sessilis (L.) R. Br. (Amaranthaceae) in mice and rats. E-International Scientific Research Journal. 2010; 2:2094-1749.

23. Yadav Sanjay Kumar, Das Sanjib. Evaluation of Anti-Diarrhoeal Property of Crude Aqueous Extract of Alternanthera sessilis Linn. International Journal of Pharmaceutical Innovations. 2013; 3(3):110-115.

24. Sahithi B, Rajani GP, Sowjanya K, Gupta D. Antiinflammatory activity of ethanolic and aqueous extracts of Alternanthera sessilis Linn. Pharmacologyonline. 2011; 1:1039-1043.

25. Song-Chow Lin, Yun-Ho Lin, Shyh-Jong Shyuu, Chung-Ching Lin. Hepatoprotective effects of Taiwan folk medicine: Alternanthera sessilis on liver damage induced by various hepatotoxins. Phytother Res. 2006; 8(7):391-398.10.

26. Roy Amit, Saraf S. Antioxidant and Antiulcer activities of an Ethnomedicine: Alternanthera Sessilis. Res J Pharm Technol. 2008; 5:369-372.

27. Johnson M, Wesely EG, Selvan N, Kavitha MS. In vivo and in vitro Antibacterial efficacy of Alternantherasessilis (Linn.). Int J Pharm Res Dev. 2010; 2(10):72-79.

28. Sunil S Jalalpure, Nitin Agrawal MB, Patil R Chimkode, Ashish Tripathi. Antimicrobial and wound healing activities of leaves of Alternanthera sessilis Linn, Int J Green Pharm. 2008; 2:141-144.

29. Pullaiah T. Encyclopedia of World Medicinal Plants, Vol 1, Published by Regency Publication, New Delhi, 2011.

30. Gupta AK. Indian medicinal plants, ICMR, New Delhi; 2004, 151-7.

31. Rastogi RP, Compendium of Indian medicinal plant, $2^{\text {nd }}$ ed., CDRI, Lucknow; 1993, 1970-9.

32. Sinha P, Arora VK, Wahi SP. Chemical investigation on Alternanthera sessilis Indian Drugs. 1984; 1:139-40

33. Mamillapalli Vani, SK Abdul Rahaman, and Avula Prameela Rani. In vivo antiasthmatic studies and phytochemical characterization on the stem extracts of Alternanthera sessilis L. using Guinea pigs model. J. Entomol. Zool. Stud. 2017; 5(2): 1160-1171.

34. Gupta R, Singh HK. Detection and Quantitation of Gallic Acid in Alternanthera sessilis and Clerodendrum infortunatum by HPTLC. Pharm Pharmacol Int J. 2016; 4(6):00097.

35. Himangsu Mondal, Sanjib Saha, Khalijah Awang, Hemayet Hossain, Abdulwali Ablat, Md Khirul Islam, et al. Central-stimulating and analgesic activity of the ethanolic extract of Alternanthera sessilis in mice. BMC Complement Altern Med. 2014; 14:398.

36. Meenakshi Sundaram M, Karthikeyan K, Sudarsanam, D and Brindha P. Antimicrobial and AnticancerStudies on Euphorbia heterophylla. J Pharm Res. 2010; 3(9):2332.
37. Apiamu Augustine, Evuen Uduenevwo Francis, Ajaja Uche Ivy. Biochemical Assessment of the Effect of Aqueous Leaf Extract Of Euphorbia Heterophylla Linn on Hepatocytes of Rats. IOSR J Environ Sci Toxicol Food Technol. 2013; 3(5):37-41

38. Annapurna and Ketan Hatware. Effect of aqueous extract of euphorbia heterophylla on blood glucose levels of alloxan-induced diabetic rats. Int. J Res. Pharm. Chem. 2014; 4(3):669-672.

39. Okolie Ngozi Paulinus, Falodun Abiodun, Agu Kinsley, Egbe Justine, Uchechukwu, Aay Keyinde, Madu Kelechi and Eijayeshina Joseph. Effect of aqueous leaf extract of Euphorbia heterophylla on kidney, liver and pancreatic functions and plasma electrolytes in rabbits. J. Pharm. Sci. 2015; 4(2):116-119.

40. Abiodun Falodun, Sajjad Ali, Irfan Mohammed Quadir and Iqbal M. Choudhary I. Phytochemical and biological investigation of chloroform and ethyl acetate fractions of Euphorbia heterophylla leaf (Euphorbiaceae). J. Med. Plants Res. 2008; 2(12):365-369

41. Rowan N.G., and D.N. Onwukaeme. Diterpenoid Esters of Euphorbiaceae in Euphorbia hyles. Nigeria Journal of Pharmacology. 2001; 32:60 - 64.

42. Falodun A and. Agbakwuru E.O.P. Phytochemical Analysis and Laxative Activity of the Leaf Extracts of Euphorbia heterophylla L. (Euphorbiaceae). Pak J Sci Ind Res. 2004; 47(5):345 - 348.

43. Markham KR. Flavones, flavonols and their glycosides. In J Harborne, ed, Methods in Plant Biochemistry, Vol 1. Academic Press, San Diego, 1993, CAP pp 197-235.

44. Wach A, Pyrzyn'ska K and Biesaga M. Quercetin content in some food and herbal samples. Food Chem. 2007; 100: 699-704

45. Shah R, Sharma N, Patel V, Savai J and Saraswathy N. Validated HPLC fingerprint analysis for Simultaneous Determination of quercetin and kaempferol in methanolic Extract of Tridox procumbens. International Journal of Pharmaceutical and Biological Research (IJPBR) 2012; 3(4):166-175.

46. Neeraj $C$ and Bhupinder SS. An overview of advances in the standardization of herbal drugs, J Pharm Educ Res. 2011; 2(2):55-70.

47. Jose Carlos Rebuglio Vellosa, Luis O. Regasini, Najeh Maissar Khalil, Vanderlan da Silva Bolzani, Omar A KK Khalil, Francine Alessandra Manente, Harli Pasquini Netto, Olga M M de Faria Oliveira. Antioxidant and cytotoxic studies for kaempferol, quercetin and isoquercitrin. Ecl.Quim.Saopaulo. 2011; 36 (2) 7-20.

48. Mahesh Kumar SK and Kirti SL. Determination of total flavonoids content and quantification of rutin in Momordica tuberosa (Roxb) Cogn. Fruits by RP-HPLC Asian J Tradit Med. 2012; 7:220-25

49. Tandon, N., and Sharma, S., Quality Standards of Indian Medicinal Plants, Vol. 8, p 13, 2010, Medicinal Plants Unit, Indian Council of Medical Research.

50. Thalapaneni Nageswara Rao, Chidambaram Kumarappan, Sabapathi Mohana Lakshmi and Subhash C Mandal. Antioxidant Activity of Talinum portulacifolium (Forssk) Leaf Extracts. Orient Pharm and Exp Med. 2008; 8(4): 329-338.

51. Shih-Huei Chen and Yi-Ching Li. Remarks on the Species of Gomphrena (Amaranthaceae) of Taiwan. Taiwania. 2012; 57(3): 312-317.

52. Friends of the wild flower garden. Available from http://www.friendsofeloisebutler.org/. [Updated 2017/September; cited 2017 September 9]

53. Omale James and Emmanuel.T. Phytochemical composition, bioactivity and wound healing Potential of Euphorbia heterophylla (Euphorbiaceae) Leaf Extract. Int J Pharm Biomed Res. 2010;1(1):54-63.

54. Apiamu Augustine, Evuen Uduenevwo Francis, Ajaja Uche Ivy. Biochemical Assessment of the Effect of Aqueous Leaf Extract Of Euphorbia Heterophylla Lin. on Hepatocytes of Rats. 2013; 3(5):37-41.

55. Thomas MWalter, S Merish, M Tamizhamuthu. Review of Alternanthera sessilis with reference to traditional Siddha medicine. International Journal of Pharmacognosy and Phytochemical Research 2014; 6(2):249-254. 
GRAPHICAL ABSTRACT

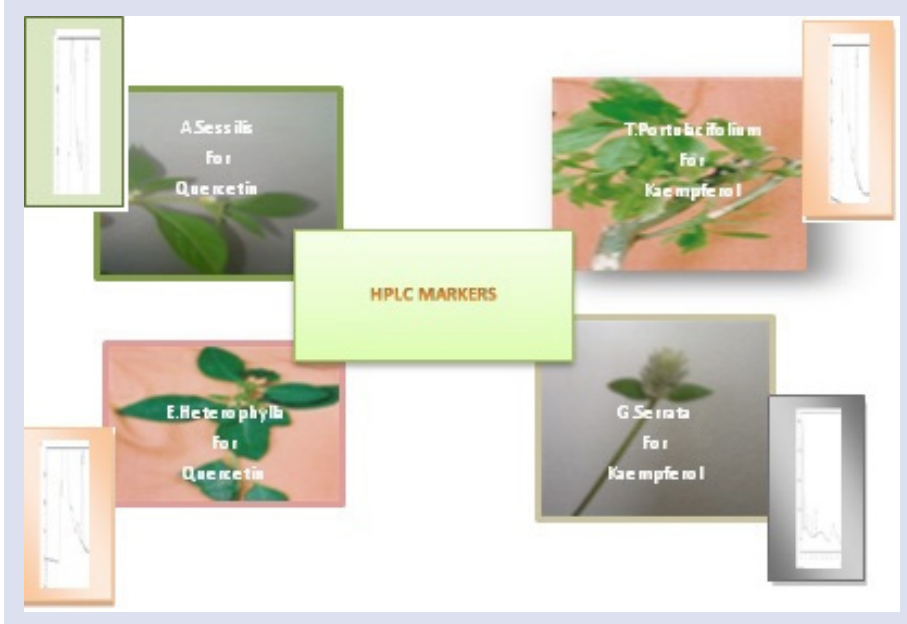

\section{SUMMARY}

- World Health Organization has been encouraging countries to identify and exploit traditional medicine and phytotherapy Chromatographic fingerprinting of herbal medicines is utilized for the authenticity and quality control of herbal medicines, which has become the most important tool for quality control of traditional herbal medicines (HPLC). The present study was to detect and quantify the phytochemical marker compounds kaempferol through HPLC analysis. HPLC spectra showed the presence of kaempferol from hydro alcoholic extracts of Talinum portulacifolium leaves and Gomphrena serrata flowers. Quercetin was phytochemicalmarker from the hydro alcoholic extracts of and Alternanthera sessilis stems and Euphorbia heterophylla stems quercetin in the plant extracts. The developed method has enabled rapid analysis of two flavonoid markers kaempferol and quercetin with marked retention time 13.72 minutes and 6.5minutes compared to standar drug. Therefore the developed method can be used as a reference for carrying out the standardization studies, and in detecting adulteration or substitution

Cite this article: Vani M, Rahaman SKA, Rani AP. Detection and Quantification of Major Phytochemical Markers for Standardization of Talinum Portulacifolium, Gomphrena serrata, Alternanthera sessilis and Euphorbia heterophylla by HPLC. Pharmacog J. 2018;10(3): 2018;10(3):439-46. 